\title{
The variation of spike times
}

\author{
Conor Houghton ${ }^{1,2^{*}}$, James B Gillespie ${ }^{1}$ \\ From Twenty First Annual Computational Neuroscience Meeting: CNS*2012 \\ Decatur, GA, USA. 21-26 July 2012
}

Spike trains are often variable with the same stimulus producing different responses from presentation to presentation. These variations can be thought of as being composed of two different types of noise; variations in the spike times and variations in the spike count. The Victor-Purpura distance metric is used to separate these two noise types, allowing the distribution in spike time variations to be calculated. The distribution is calculated for a collection of example data sets. For these data, the distributions are not Gaussian but, in most cases, they can be accurately modeled by a hyper-Laplace distribution.

\section{Author details}

${ }^{1}$ School of Mathematics, Trinity College Dublin, Dublin 2, Ireland.

${ }^{2}$ Department of Computer Science, University of Bristol, BS8 1UB, UK.

Published: 16 July 2012

doi:10.1186/1471-2202-13-S1-P132

Cite this article as: Houghton and Gillespie: The variation of spike times. BMC Neuroscience 2012 13(Suppl 1):P132.

\footnotetext{
*Correspondence: conor.houghton@gmail.com

'School of Mathematics, Trinity College Dublin, Dublin 2, Ireland
}

Full list of author information is available at the end of the article

Submit your next manuscript to BioMed Central and take full advantage of:

- Convenient online submission

- Thorough peer review

- No space constraints or color figure charges

- Immediate publication on acceptance

- Inclusion in PubMed, CAS, Scopus and Google Scholar

- Research which is freely available for redistribution 